business by Miki's (still very useful) list. A Record of Writing is more successful as a primary bibliography than a secondary one.

The Index to A Record of Writing is a very real pleasure to explore for anybody who is interested in consolidating extensive information on any given poem by Bowering. Some bibliographic formats tend to put the onus on the reader to read all sections of a bibliography before they can - or as the only way they can - determine everything that is around or available on a particular item. Fortunately, A Record of Writing works better than that at the desk or the elbow level. If, for example, you wish to research the poem 'Grandfather,' the index will send you (by item listing rather than page number) to the 34 places throughout the bibliography where it comes up as a title. Similarly, it will send you off to the 2 I places where the poetry volume Curious is referred to or to the 75 where Craft Slices is visible in various contexts. As well, all persons, presses and publications associated with Bowering in any way in the bibliography are given a full listing in the index in case it is a milieu, publication history, another person, etc. that the reader is interested in. This is a fascinating bibliography to ready throughout as a sort of 'Book of Bowering, but it is also a big relief to know that you do not have to read it cover to cover every time you want to be thorough about something highly specific to your research needs. The index to A Record of Writing is the final mark of good competence in this bibliography, and nobody will seriously fault the good sense of its format.

In his preface to A Record of Writing, Miki indicates that he will feel satisfied with his bibliographical harvest if it

... initiates curiosity and offers readers the larger perspective which can lead to a fuller understanding of both writer and work. Like any scholarly venture, though, a bibliographic project is fraught with the spectre of error and the ghosts of those entries omitted (absences in the margins) that will someday materialize. What is frozen in place here is already obsolete - yet such a notion in no way subtracts from the brilliance of GB's record of writing so far (pp. ix-x).

Miki has succeeded exceptionally well with A Record of Writing, and he has created a book that lifts the art of bibliography to a cut above the standard form. George Bowering should be jumping with joy.

TERRY WHALEN

Saint Mary's University

Fraser Sutherland. The Monthly Epic: A History of Canadian Magazines. Markham, Ont.: Fitzhenry \& Whiteside, I989. vii, [I], 355, [I] pp.; $\$ 40.00$ (paper boards). Is BN 0-88902-897-4.

Fraser Sutherland is a freelance writer, an author of nine books, whose strongest publications have been in poetry and fiction. For the past twenty years or so he has worked to nurture his craft and survive in the hardscrabble and thin soil of the 
contemporary Canadian literary scene, first in Nova Scotia and more recently in Ontario. While it is fashionable at present to speak glowingly of the vibrant health of Canadian writing, the truth is the rich ground is occupied by a relatively small number of fleshy plants which, pampered by an adoring public and a manipulative publishing industry, bask complacently in their own glory and extend their tentacles to grasp just about everything that is worth having. Outside the precincts of Harbourfront (where literary activity is largely a spectator sport), the going is still tough; the economic returns are generally smaller than the imaginative energy required, making the price of artistic survival increasingly steep. In order to garner a viable income and some degree of professional recognition, writers like Sutherland find it necessary to distribute their energies across a broad spectrum of pseudo-literary activities: various forms of editorships, writer-in-residence-ships, creative writing guru-ships, and reportorial and journalistic dabblings. All these are essentially ephemeral activities for creative writers and ones which may not be particularly well-suited to their imaginative talents - which brings us to the volume under review.

The idea of writing a history of Canadian magazines is an attractive one. The problem is how to approach the task in light of our uneven knowledge of the subject. The job is far from being a straightforward one. Where information is scanty there is a pressing need for original academic research, evaluation and interpretation; where information is fuller, a need for narrative clarification and imaginative presentation. These two intellectual functions are quite different from one another, reflecting perhaps distinctly different casts of mind; and rarely does one find an historical text which is both academically convincing and journalistically satisfying. Regrettably, The Monthly Epic is not among those few.

In approaching the task, Sutherland had neither the academic training nor the financial resources to do the kind of original research and interpretation that large sections of his subject still require. Understandably, he has leaned heavily on secondary sources, but at many critical points in his narrative those studies have simply been too weak, outdated or superficial to support and sustain the credibility of the text. Not surprisingly, the unevenness of his sources has resulted in an uneven, out of balance, and at times confused picture of Canadian magazine history. Most notable is the relatively limited and superficial treatment afforded nineteenth-century Canadian magazine activity. From an historical point of view, the periodical press of nineteenth-century Canada (before the competition of radio, film, and television) appears to have been more instrumental in focusing, shaping, and charting our cultural and intellectual development than at any other point in our history. I say 'appears to have been' because the research to marshal the conclusive evidence to confirm this view has not been performed. We are still going back to forty-year-old theses and (like Sutherland and his outdated sources) are still fishing in the dark here. The insufficient and often fragmentary information that we have suggests that the nineteenth century was an extremely significant period in Canadian magazine history, but as yet we have not done enough basic research to clarify why it was important and just what it contributed to our social and cultural development in general. Throughout this critical part of Sutherland's book, we are still expected to stifle our curiosity and take the importance of it all on faith, so that we can get on to 


\section{Books in Review}

the apparently more important history in the twentieth century. Sutherland's somewhat cursory treatment of the first I 2O-odd years of Canadian magazine history is both a reflection of the dearth of available information and an admission that he has nothing new to contribute.

Another deficiency that flows from relying on inadequate secondary sources is Sutherland's failure to identify and develop pertinent influences and contexts that have not been discussed at any length by previous commentators. One would almost think that the magazines Sutherland discusses developed in a socio-cultural, even a literary and intellectual vacuum. He gives us little sense of the broader context, its constituent parts and how these relate to the activity he focuses on. Nor does his caveat in the introduction excuse him from this responsibility. There is no acknowledgement of the place of religious magazines and the role they play in developing moral and social consciousness. There is no treatment of the British and American competition and the influence that these have had on content and form in addition to influencing the economics of the business. No mention is made of the role of university magazines (as distinct from scholarly journals); many are among the longest running and most stable titles, and provided an apprenticeship for some of our most notable authors. Without adding further to this litany of omissions, there is ample evidence here that the history of Canadian magazines is considerably more complex, more problematic, more varied, and more intriguing than Sutherland's book would suggest. His dependence on limited resources necessarily results in an unintentional superficiality.

But the final disservice of this work is to the author himself. Sutherland is a good writer but his material here betrays him. His efforts to bring the facts together into a logically cohesive and coherent narrative (without resorting to fiction) at times fail badly. There are paragraphs where his prose has all the compositional logic of gravel. A good copy editor might have solved some of these problems, but in many instances a lack of connecting material simply results in a confusing babble of facts.

What this book does do, however, is demonstrate that Canadian magazine history is inherently interesting and frequently lively, and that it is spiced with some fascinating personalities. It makes us want to know more about the subject - both as scholars and general readers. The problems which plague this book demonstrate that the current state of available information cannot provide us with a convincing or detailed enough picture of Canadian magazine history. We need more and better biographies, more cultural studies, more intellectual analyses before the book that Sutherland would like to have written can be written. I would recommend this book to students of Canadian social and cultural history who are looking for interesting thesis topics.

THOMAS B. VINCENT

Royal Military College 